\title{
Compatibility of Entomopathogenous Fungi with Commonly used Insecticides for Management of Banana Aphid transmitting Banana bunchy Top virus (BBTV) in Assam Banana Production System
}

\author{
Nilakshi Kakati*, P. Dutta, P. Das and P.D. Nath \\ Department of Plant Pathology, Assam Agricultural University, Jorhat-785013, Assam, India \\ *Corresponding author
}

\section{A B S T R A C T}

\begin{tabular}{l} 
Key w or d s \\
Entomopathogenic \\
fungi, Beauveria \\
bassiana, \\
$\begin{array}{l}\text { Metarhizium } \\
\text { anisopliae, } \\
\text { Verticillium lecanii, } \\
\text { Pesticides }\end{array}$ \\
Article Info \\
$\begin{array}{l}\text { Accepted: } \\
18 \text { October } 2018 \\
\text { Available Online: } \\
\text { 10 November } 2018\end{array}$ \\
\hline
\end{tabular}

Keywords

Entomopathogenic fungi, Beauveria bassiana, Verticillium lecanii, Pesticides

\section{Introduction}

To control the secondary infection of Banana bunchy Top virus (BBTV) transmitted by its insect vector Pentalonia nigronervosa in banana field there is a need to find out alternative agents that are pest specific, nontoxic, biodegradable, safe to natural enemies, less prone to resistance and less expensive. In the integrated pest management (IPM) schedule against the insect-vector, inclusion of neem based formulations as well as biocontrol agents (BCAs) like entomopathogenic fungi

\begin{abstract}
The three entomopathogenic fungi viz., Beauveria bassiana (Bals.) Vuill., Metarhizium anisopliae (Metchnikoff) Sorokin and Verticillium lecanii were tested for their compatibility with three insecticides used in banana production system in in vitro by poinson food technique. All the insecticides were tested for their compatibility with each fungi at three different concentrations i.e., recommended dose (RD), half of the RD and one fourth of the RD. $V$. lecanii was found highly compatible with all the insecticides followed by $B$. bassiana. The concentration $1 / 4 \mathrm{RD}$ of all the insecticides was found safe showing higher mycelial growth of the fungi. Imidacloprid $17.8 \% \mathrm{SL}$ at $0.025 \%$ showed no inhibition $(0.00 \%)$ of $V$. lecanii followed by 9.81 per cent to $B$. bassiana. Dimethoate $30 \mathrm{EC}$ at $0.05 \%$ showed maximum inhibition of 21.25 per cent of $V$. lecanii followed by 27.81 per cent to B. bassiana. The botanical insecticide Azadirachtin at $0.075 \%$ showed maximum inhibition of 22.94 per cent of $V$. lecanii followed by 35.19 per cent to $B$. bassiana. Present investigations showed effects of pesticides on the fungi, their actual effects at cellular and field level need to be investigated for the efficient utilization of entomopathogens in the integrated pest management of banana.
\end{abstract}

has been adopted globally (Alves and Lecuona, 1998; Ramarethinam et al., 2004). A lot of examples exist where application of different selective chemical insecticides and fungi when used in combination provide satisfactory control against many agricultural insect pests (Serebrove et al., 2005; Purwar and Sachen, 2006). On the other hand, the use of non selective or incompatible chemical pesticides may possibly have the potential to hinder the vegetative growth and development of fungi adversely affecting the IPM (Duarte et al., 1992 and Malo, 1993). For this reason, 
an understanding about the adverse effects of different insecticides on entomopathogenic fungi is necessary. A number of experiments have been done to evaluate the deleterious effects of chemical insecticides on different developmental stages of fungi (Alialzadeh $e t$ al., 2007). The effect of these products may vary in different species and strains of fungi (Anderson et al., 1989). The results from such experimental work would direct the farmers to choose a more compatible pesticides and the adverse effects of the injudicious use of insecticides can be minimized (Butt et al., 2001 and Inglis et al., 2001). Therefore there is a need to manipulate the inhibitory effects of different insecticides on the mycelial growth and sporulation of isolates of different BCAs, as well as, to check the compatibility of these chemicals with these BCAs.

\section{Materials and Methods}

The three entomopathogenic fungi viz., Beauveria bassiana (Bals.) Vuill., Metarhizium anisopliae (Metchnikoff) Sorokin and Verticillium lecanii used in this study were collected from culture collection of Mycology Research Section, Department of Plant Pathology, Faculty of Agriculture, AAU, Jorhat. All the three organisms were cultured on PDA medium in $8 \mathrm{~cm}$ petri dishes and incubated at $25 \pm 2{ }^{\circ} \mathrm{C}$ temperature. Three different pesticides viz., Azadirachtin $(0.15 \%)$ @ 3 $\mathrm{ml} / 1$ (Margosom), Imidacloprid 17.8\% SL @ 1 $1 \mathrm{ml} / 1$ (Imidacel) and Dimethoate $30 \mathrm{EC}$ $(0.06 \%) @ 2 \mathrm{ml} / 1$ (Rogor) used in banana production system were selected to assess the compatibility with BCAs. For compatibility tests the pesticides were used in three different concentrations, i.e., recommended dose (RD) (lethal), half of the recommended dose (1/2 RD) (sub lethal) and one fourth of the recommended dose ( $1 / 4 \mathrm{RD})$ (sub-sub lethal).

Standard poisoned food technique was followed to assay the in vitro compatibility of entomopathogens with the different pesticides (Nene and Thapliyal, 1997) (Plate 1). Quantity of pesticides used was based on field application rate with high volume sprayer. Standard PDA medium $(30 \mathrm{ml})$ was autoclaved at $121^{\circ} \mathrm{C}$ for 15 minutes, cooled to $40 \pm 5^{\circ} \mathrm{C}$, and amended with $0.3 \mathrm{~g} / \mathrm{l}$ of streptomycine sulphate. The required concentrations (RD, $1 / 2 \mathrm{RD}$ and $1 / 4 \mathrm{RD}$ ) of pesticides $(30 \mathrm{ml}$ each) were prepared and added to the media while it was warm and agitated thoroughly to get a uniform distribution of pesticides in the media. For control plates, appropriate amount of streptomycine sulphate $(0.3 \mathrm{~g} / \mathrm{l})$ alone was added.

Approximately $15 \mathrm{ml}$ of each of the amended media was poured aseptically into $8 \mathrm{~cm}$ sterilized petri dishes. The same amount of medium without the pesticides was used as control for comparison under the same conditions. Mycelial disc (5mm diameter) of young fungal mycelium was cut with sterile cork borer and placed aseptically in the centre of each petri dish containing the poisoned medium. Inoculated petri dishes were incubated at $27 \pm 1^{\circ} \mathrm{C}$, and $80 \pm 5$ per cent relative humidity. For each treatment four replications were maintained. Suitable check without poison was kept for comparison under the same condition. Fungal colony diameter was measured with a caliper ruler after every 24 hrs of inoculation till full growth was observed in control plates. Percent inhibition of radial growth of fungal isolate over untreated check was worked out for the respective chemicals by following the formula:

Per cent inhibition of radial growth $=$

$\frac{(\mathrm{C}-\mathrm{T})}{\mathrm{C}} \times 100$

Where, $\mathrm{C}=$ colony diameter of $\mathrm{BCA}$ in control 
$\mathrm{T}=$ colony diameter of $\mathrm{BCA}$ in treatments

Further, the data were statistically analysed and critical difference $(\mathrm{CD})$ calculated at $\mathrm{P}=$ 0.05 . The experiment was laid out in Completely Randomized Block Design (CRD) with 30 treatments in 4 replications. Fisher's Method of analysis of variance was followed for statistical analysis of the experimental data. Significance of variance among data were calculated out by calculating the ' $\mathrm{t}$ ' at 5 per cent probability level. Different treatment means were compared with critical difference (C.D.). Means were separated by Duncan's Multiple Range Test (DMRT).

\section{Results and Discussion}

In vitro, evaluation of compatibility of different biocontrol agents (BCAs) with botanical and chemical pesticides showed that $V$. lecanii was highly compatible with all the pesticides followed by $B$. bassiana and $M$. anisopliae (Table 1). The maximum growth of the BCAs were recorded at $1 / 4 \mathrm{RD}$ (sub-sub lethal dose) followed by $1 / 2 \mathrm{RD}$ (sub lethal) and RD (lethal) of the three pesticides. Among the pesticides tested, Imidacloprid at $0.025 \%$ $(1 / 4 \mathrm{RD})$ showed maximum radial growth of $80.00 \mathrm{~mm}$ in the treatment combination of Imidacloprid @ $0.025 \%+V$. lecanii with no inhibition $(0.0 \%)$ on growth of the fungus followed by $72.15 \mathrm{~mm}$ in Imidacloprid @ $0.025 \%+B$. bassiana and $55.35 \mathrm{~mm}$ in Imidacloprid @ 0.025\% + M. anisopliae. The per cent inhibition of radial growth of $B$. bassiana and $M$. anisopliae over control was found to be 9.81 and 11.51per cent, respectively. Dimethoate at $0.05 \%$ ( $1 / 4 \mathrm{RD})$ showed highest radial growth of $63.00 \mathrm{~mm}$ with growth inhibition of 21.25 per cent in combination of $V$. lecanii followed by $B$. bassiana with $57.75 \mathrm{~mm}$ growth and 27.81 per cent growth inhibition. This was followed by $M$. anisopliae with $24.35 \mathrm{~mm}$ growth and 61.07 per cent inhibition. The maximum radial growth or colony diameter of the three BCAs with Azadirachtin was recorded at the one fourth concentration of the recommended dose $(1 / 4 \mathrm{RD})$ i.e., 0.075 per cent. Azadirachtin@ $0.075 \%+V$. lecanii showed $61.65 \mathrm{~mm}$ growth with 22.94 per cent inhibition followed by Azadirachtin @ $0.075 \%+$ B. bassiana $(51.85 \mathrm{~mm}$ and 35.19 per cent $)$ and Azadirachtin @ 0.075\% + M. anisopliae (25.90 $\mathrm{mm}$ and 58.59 per cent), respectively.

The highly compatible nature of $V$. lecanii with different pesticides were observed by $\mathrm{Li}$ et al., (2002), Derakhsan (2006), Manjunatha et al., (2006), Madhavji (2007) and Alizadeh et al., (2007) who reported the least inhibition of mycelial growth of $V$. lecanii with Imidachloprid, neem seed karnel extract(NSKE) and Dimethoate. They also reported that these chemicals were less toxic even at their recommended dose of field application. Sharma and Gupta (1998) reported that Azadirachtin $(0.03 \%$ EC), compatible with B. bassiana even upto 2000 ppm. The results of evaluation of compatibility of $B$. bassiana were in accordance with that of Azadirachtin and Dimethoate as reported by Puzari et al., (2006). Similar results were observed when compatibility of $B$. bassiana was evaluated with Imidachloprid by Alizadeh et al., (2007). The fungal biocontrol agents and pesticides may act synergistically increasing the efficiency of the control, allowing lower doses of pesticides (Moino and Alves, 1998). Further, compatible combination can reduce the cost of cultivation by reducing the time of application of different component singly. The observed variations in the inhibitory potential could be due to inherent variability of chemical insecticide to biocontrol agents. Their inhibitory potential varies both between and within chemical classes (Inglis et al., 2001). A given insecticides may have different fungitoxic effects on various developmental stages of the fungus (Li and Holdom, 1994). 
Table.1 In vitro compatibility of Biocontrol agents (BCAs) with botanical and chemical pesticides

\begin{tabular}{|c|c|c|}
\hline Treatment combinations (Pesticides+ BCA) & $\begin{array}{l}\text { Radial } \\
\text { growth of } \\
\text { BCA } \\
(\mathrm{mm})^{*}\end{array}$ & $\begin{array}{c}\text { Per cent } \\
\text { Inhibition of } \\
\text { radial growth } \\
\text { over control }\end{array}$ \\
\hline Azadirachtin (0.15\%) @ $0.075 \%+$ B. bassiana & $51.85^{\mathrm{efg}}$ & 35.19 \\
\hline Azadirachtin (0.15\%) @ 0.15\% + B. bassiana & $36.90^{\mathrm{h}}$ & 53.88 \\
\hline Azadirachtin (0.15\%) @ $0.3 \%+$ B. bassiana & $19.75^{\mathrm{klmn}}$ & 75.31 \\
\hline Azadirachtin (0.15\%) @ $0.075 \%+$ M. anisopliae & $25.90^{\mathrm{jkl}}$ & 58.59 \\
\hline Azadirachtin (0.15\%) @ $0.15 \%+$ M. anisopliae & $17.40^{\mathrm{mn}}$ & 72.18 \\
\hline Azadirachtin (0.15\%) @ $0.3 \%+$ M. anisopliae & $15.40^{\mathrm{n}}$ & 75.38 \\
\hline Azadirachtin (0.15\%) @ $0.075 \%$ + V. lecanii & $61.65^{\mathrm{d}}$ & 22.94 \\
\hline Azadirachtin (0.15\%) @ $0.15 \%+$ V. lecanii & $51.00^{\mathrm{fg}}$ & 36.25 \\
\hline Azadirachtin (0.15\%) @ $0.3 \%+$ V. lecanii & $45.60^{\mathrm{g}}$ & 43.00 \\
\hline Imidacloprid 17.8\% SL @ 0.025\% + B. bassiana & $72.15^{b}$ & 9.81 \\
\hline Imidacloprid 17.8\% SL @ 0.05\% + B.bassiana & $34.50^{\text {hi }}$ & 56.88 \\
\hline Imidacloprid 17.8\% SL @ 0.1\% + B. bassiana & $25.70^{\mathrm{jkl}}$ & 67.88 \\
\hline Imidacloprid 17.8\% SL @ $0.025 \%+$ M. anisopliae & $55.35^{\mathrm{def}}$ & 11.51 \\
\hline Imidacloprid 17.8\% SL @ $0.05 \%+$ M. anisopliae & $46.40^{\mathrm{g}}$ & 25.81 \\
\hline Imidacloprid 17.8\% SL @ 0.1\% + M. anisopliae & $26.15^{\mathrm{jkl}}$ & 58.19 \\
\hline Imidacloprid17.8\% SL@0.025\% + V. lecanii & $80.00^{\mathrm{a}}$ & 0.00 \\
\hline Imidacloprid 17.8\% SL @0.05\% + V. lecanii & $69.20^{\mathrm{bc}}$ & 13.50 \\
\hline Imidacloprid17.8\% SL @0.1\%+V. lecanii & $30.65^{\text {hij }}$ & 61.69 \\
\hline Dimethoate 30EC $(0.06 \%) @ 0.05 \%+$ B. bassiana & $57.75^{\text {def }}$ & 27.81 \\
\hline Dimethoate 30EC (0.06\%) @ 0.1\% + B. bassiana & $37.10^{\mathrm{h}}$ & 53.63 \\
\hline Dimethoate 30EC (0.06\%) @ 0.2\% + B. bassiana & $31.20^{\text {hij }}$ & 61.00 \\
\hline Dimethoate 30EC (0.06\%) @ 0.05\% + M. anisopliae & $24.35^{\mathrm{jklm}}$ & 61.07 \\
\hline Dimethoate 30EC (0.06\%) @ 0.1\%+M. anisopliae & $27.25^{\mathrm{ijk}}$ & 56.43 \\
\hline Dimethoate 30EC (0.06\%) @ 0.2\% + M. anisopliae & $19.25^{\operatorname{lm} n}$ & 69.22 \\
\hline Dimethoate 30EC (0.06\%) @ 0.05\% + V. lecanii & $63.00^{\text {cd }}$ & 21.25 \\
\hline Dimethoate 30EC (0.06\%) @ 0.1\% + V. lecanii & $58.85^{\text {de }}$ & 26.44 \\
\hline Dimethoate 30EC (0.06\%)@ 0.2\%+V. lecanii & $30.00^{\mathrm{hij}}$ & 62.50 \\
\hline B. bassiana alone (control) & $80.00^{\mathrm{a}}$ & \\
\hline M. anisopliae alone (control) & $62.55^{\mathrm{cd}}$ & \\
\hline V. lecanii alone (control) & $80.00^{\mathrm{a}}$ & \\
\hline SEd & 0.35 & \\
\hline $\mathrm{CD}(\mathbf{P}=\mathbf{0 . 0 5})$ & 0.69 & \\
\hline $\mathrm{CV}$ & 10.96 & \\
\hline
\end{tabular}

*Data are mean of four replications

Mean followed same letter are at par with each other 
Plate.1(a-i) A general view of in vitro compatibility test of entomopathogenic fungi with pesticides

d. Beauveria bassiana

e. Metarhizium anisopliae

f. Verticillium lecanii

g. Azadirachtin $(0.15 \%)$

h. Imidacloprid (17.8\% SL)

i. Dimethoate (30EC, $0.06 \%$ )

(Where, 1: One fourth of recommended dose (RD), 2: Half of RD, 3: RD and 4: Control)
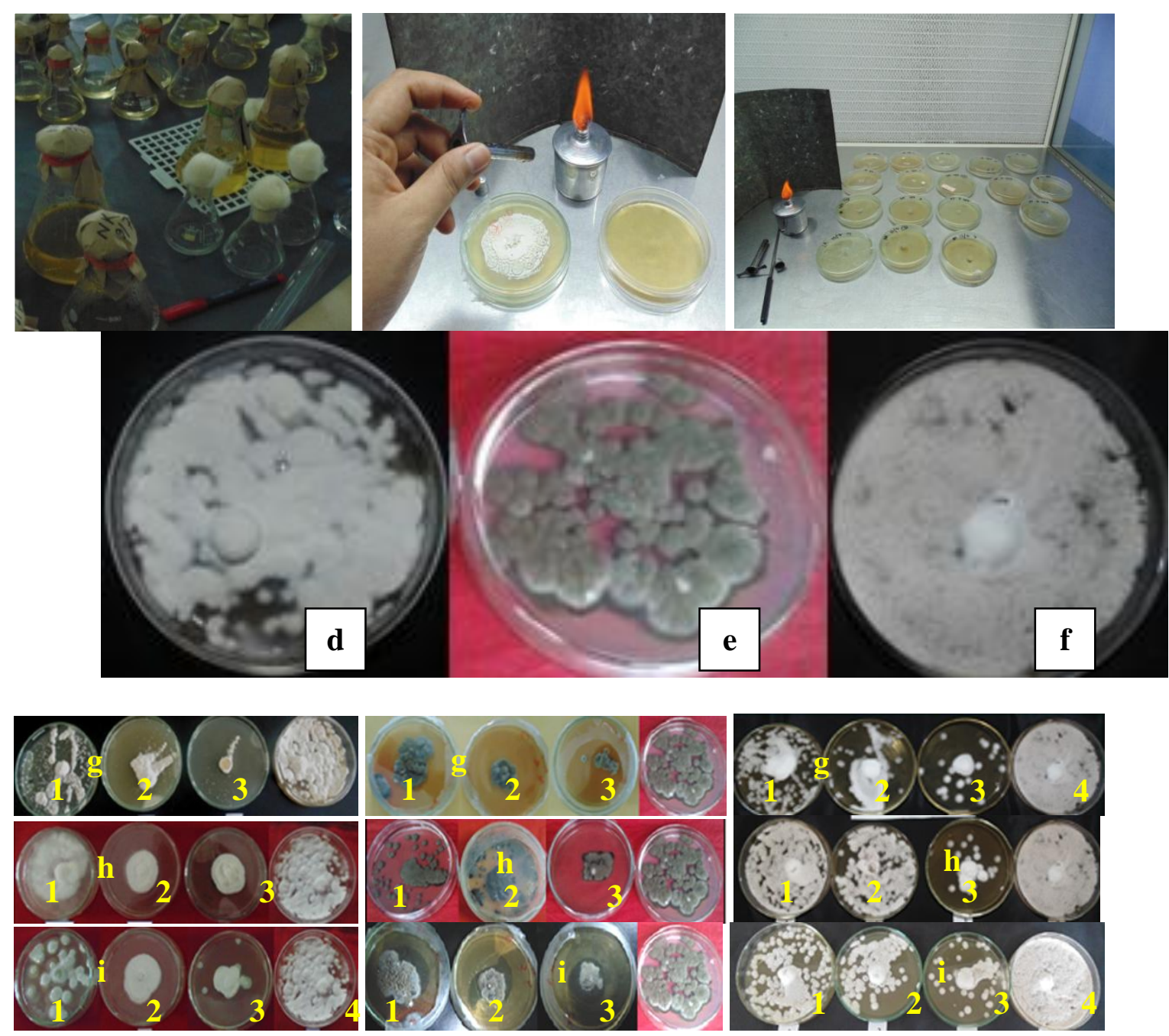

The potential inhibitory effects of pesticides on germination and mycelia growth of biocontrol fungi vary from taxa and strains (Anderson et al., 1989). However results may differ in field because fungi are exposed maximum to pesticides in vitro which doesn't occur under field conditions. Additionally, fungi may recover after some chemical pesticides are decomposed on plant leaves. Therefore, once a chemical insecticide is proved to be compatible in the laboratory, it must be selective in field conditions. On the other hand, high in vitro toxicity of the product will not always be same in the field 
(Butt and Brownbridge, 1997) but is likely to be occur (Alves et al., 1998). Present investigations showed varying effects of pesticides on the fungi, their actual effects at cellular and field level need to be investigated to understand if the effects are permanent or temporary. In case of temporary arrest of fungus activity, it may recover after degradation of toxicant and such chemicals can be employed in combination with the fungus under field conditions. The results for Compatibility analysis of biocontrol agents with chemical and botanical pesticides used in banana production system are of permanent importance in developing strategies for the efficient utilization of entomopathogens in the integrated pest management of banana.

\section{References}

Alizadeh, A., M. A. Samih and Izadi, H. 2007. Compatibility of Verticillium lecani (Zimm.) with several pesticides. Commun. Agric. Appl. Biol. Sci., 72(4): 1011-5.

Alves, S. B. and Lecuona, R. E. (1998). Epizootiologia aplicada ao controle microbiano de insetos, In: Controle microbiano de insetos S.B. Pp. 97-170.

Alves, S. B., Jr. A. Moino and Almeida, J.E.M. 1998. Produtos fitossanitarios e entomopathogenos. In: Controle microbiano de insectos. Piracicaba. (Ed): S.B. Alves. FEALQ, pp. 217-238.

Anderson, T. E., A.E. Hajek, D.W. Roberts, K. Preisler and Robertson, J.L. 1989. Colorado potato beetle (Coleoptera: Chrysomelidae): Effects of combinations of Beauveria bassiana withinsecticides. J. Econ. Entomol. 82(1): 83-89.

Butt, T. M. and Brownbridge, M. 1997. Fungal pathogens of thrips. In: Thrips as crop pests. (Ed.): T. Lewis. CAB International, Wallingford, UK. Pp. 399- 433.
Butt, T. M., C. W. Jackson and Magan, N. 2001. Fungal biological control agents: Progress, Problems and Potential. CABI International, Wallingford, Oxon, UK, pp 377-384.

Derakhshan, A. 2006. Effect of pesticides on entomopathogenic fungus, Verticillium lecanii. Insect Environment, 12(2): 6769.

Duarte, A., J. M. Menendez and Trigueiro, N. 1992. Estudio preliminar sobre la compatibilidad de Metarhizium anisopliae com algunos plaguicidas quimicos. Revista Baracoa, 22: 31-39.

Inglis, G. D., M. S. Goettel, T. M. Butt and Strasser, H. 2001. Use of hyphomycetous fungi for managing insect pests. In: Fungi as biocontrol agents progress, problems and potential. Butt, T. M., Jackson, C. and Magan, N. (Eds.) CAB International, UK, pp 2370.

Li, D.P. and Holdom, D.G. 1994. Effects of pesticides on growth and sporulation of Metarhizium anisopliae (Deutromycotina: Hypomycets). J. Invertebr. Pathol., 63: 209-211.

Li, X. M., K. Wang, Q. Liu, C. Xu and WeiJun, L. 2003. Effect of common pesticides on mycelial growth of Verticillium lecanii in protected area. Plant Protection, 29(5): 19-21.

Madhavji, P. G. 2007. Bio-efficacy of fungal bio-pesticides against Lipaphis erysimi (kaltenbach) infesting mustard. Ph. D. Thesis. Junagadh Agricultural University, Junagadh.

Malo, A. R. 1993. Estudio sobre la compatibilidad del hongo Beauveria bassaina (Bals.) Vuill. conformulaciones comerciales de fungicidas e insecticidas. Revista Colombiana de Entomologia, 19: 151158.

Manjunatha, S., S. Rekha, S. Subha and Naik, M. I. 2006. Evaluation of compatibility 
of insecticides with entomopathogenic fungi on arecanut. Insect Environment, 12(3): 114-115.

Moino, Jr. A.R. and Alves, S.B. 1998. Efeito de Imidachloprid e Fipronil sobre Beauveria bassiana (Bals.) Vuill. E Metarhirzium anesopliae (Metsch.) Sorok. E no comportamento de limpeza de Heterotermies tenuis (Hagem). Anais da Sociedade Entomologica do Brasil, 27: 611-619.

Nene, Y. L. and Thapliyal, P. N. 1997. Fungicides in Plant Disease Control. Oxford and IBH Publishing Co. Pvt. Ltd., New Delhi, p. 531.

Purwar, J. P. and Sachan, G. C. 2006. Synergistic effect of entomogenous fungi on some insecticides against Bihar hairy caterpillar Spilarctia oblique (Lepidoptera: Arctiidae). Microbiol. Res., 161(1): 38-42.

Puzari, K. C., L. K. Hazarika, P. Dutta and Das, P. 2006. In vitro inhibition of
Beauvaria bassiana (Bals.) Vuill. growth by different commonly used insecticide in rice. J. Biol. Control, 20(1): 51-56.

Ramarethinam, S., Marimuthu, S. and Murugesan, V. (2004). Effect of Nimbicidine (0.03\% Azadirachtin) on the major insect pest and their natural enemies of rice, Oryza sativa Linn. in South India. Pestology, 28(7): 27-32.

Serebrov, V.V., V.P. Khodyrev, O. N. Gerber and Tsvetkova, V.P. 2005. Per spectives of combined use of entomopathogenic fungi and chemical insecticides against Colorado Beetle (Leptinotarsa decemlineata). Mikologiya I Fitopatologiya, 39(3): 89-98

Sharma, S. and Gupta, R. B. L. (1998). Compatibility of Beauveria brongniartii with pesticides and organic manures. Pest. Res. J., 10(2): 251-253.

\section{How to cite this article:}

Nilakshi Kakati, P. Dutta, P. Das and Nath, P.D. 2018. Compatibility of Entomopathogenous Fungi with Commonly used Insecticides for Management of Banana Aphid transmitting Banana bunchy Top virus (BBTV) in Assam Banana Production System. Int.J.Curr.Microbiol.App.Sci. 7(11): 2507-2513. doi: https://doi.org/10.20546/ijcmas.2018.711.285 